\title{
Assessment of Physicochemical Characteristics of Lower River Niger at Kpata, Adankolo and Gadumo Stations in Kogi State, Nigeria
}

\author{
*OGBE, KU; ADEJOH, OS; DASUMA, E
}

\author{
Department of Fisheries and Aquaculture, Kogi State University, Anyigba, Kogi State, Nigeria
}

*Corresponding Author Email: ogbekingsley90@gmail.com

\begin{abstract}
The present work was conducted to study the physicochemical parameters of lower River Niger at Lokoja and Ajaokuta local government area of Kogi state, with the aims to determine the physical and chemical situation of the River at this point in time, compare the physical and chemical situation of the river with earlier work done on River Niger and other relevant water bodies by relevant authors also to determine its suitability for fish growth and survival at this point in time. Water samples were collected for four month (January to April) at three sampling site (two site from Lokoja and one from Ajaokuta local government area) and analysed for various physicochemical parameter. The mean temperature values ranged from $23.55-28.35^{\circ} \mathrm{C}$ at Kpata station, $24.65-29.75^{\circ} \mathrm{C}$ at Adankolo station and $23.90-28.90^{\circ} \mathrm{C}$ at Gadumo station. The mean $\mathrm{pH}$ values ranged from 6.69-8.15 at Kpata station, 6.60-8.30 at Adankolo station and 6.10-8.20 at Gadumo station. The mean electrical conductivity values ranged from $68.50-135.50 \mu \mathrm{S} / \mathrm{cm}$ at Kpata station, $68.00-122.50 \mu \mathrm{S} / \mathrm{cm}$ at Adankolo station and $68.00-122.50 \mu \mathrm{S} / \mathrm{cm}$ at Gadumo station. The mean dissolved oxygen (DO) values ranged from $6.10-9.30 \mathrm{mg} / 1 \mathrm{at}$ Kpata station, 5.65-7.78 mg/l at Adankolo station and 6.10-9.30 mg/l at Gadumo station. The mean transparency values ranged from $0.31-0.60 \mathrm{~m}$ at Kpata station, $0.31-0.60 \mathrm{~m}$ at Adankolo station and $0.30-0.44 \mathrm{~m}$ at Gadumo station. The mean biochemical oxygen demand (BOD) values ranged from 2.10-2.95 mg/l at Kpata station, 2.05-3.25 mg/l at Adankolo station and $2.10-4.00 \mathrm{mg} / \mathrm{l}$ at Gadumo station. The mean nitrate values ranged from $0.02-0.05 \mathrm{mg} / \mathrm{l}$ at $\mathrm{Kpata}$ station, $0.02-0.03 \mathrm{mg} / \mathrm{l}$ at Adankolo station and $0.02-0.04 \mathrm{mg} / \mathrm{l}$ at Gadumo station. The mean phosphate values ranged from $0.48-0.61 \mathrm{mg} / \mathrm{l}$ at Kpata station, $0.51-0.65 \mathrm{mg} / \mathrm{l}$ at Adankolo station and $0.49-0.64 \mathrm{mg} / 1$ at Gadumo station. The study indicated that the mean value of the studied parameters which include $\mathrm{pH}$, temperature, dissolved oxygen, Electrical conductivity, biochemical oxygen demand, nitrate, transparency and phosphate of the River compares slightly favourably with the work of other researchers and within the range that support fish growth and survival. This indicates that the river is in a healthy state and is favourable for fish growth and survival.
\end{abstract}

DOI: $\underline{\text { https://dx.doi.org/10.4314/jasem.v24i10.3 }}$

Copyright: Copyright $\odot 2020$ Olanipekun and Togun. This is an open access article distributed under the Creative Commons Attribution License (CCL), which permits unrestricted use, distribution, and reproduction in any medium, provided the original work is properly cited.

Dates: Received: 16 August 2020; Revised: 22 September 2020; Accepted: 18 October 2020

Keywords: physiochemical parameter, water, river Niger, fish growth

Most of the earth is covered by water, about $70 \%$ is occupied by freshwater and oceans. The vast majority of that water, however, is in forms unavailable to landbased or freshwater ecosystems. Less than 3 percent is freshwater, most of which are not potable for drinking, or easily available to irrigate crops. And of that $30 \%$, more than two-thirds is locked in glaciers and ice caps. Freshwater lakes and Rivers hold 100,000 $\mathrm{km}^{3}$ globally, less than one ten-thousandth of all water on earth (Jackson et al., 2001). On earth, water is an essential natural resource for sustaining life and the environment (Dikio, 2010). One of the key sources of water supply is Riverine system, all around the globe, which provide water for agriculture, drinking, industrial and many other purposes (Malik et al., 2012; Ullah et al., 2014b). Rivers are invaluable ecological resources that serves many human needs and therefore, enhance our lives by providing a lot of opportunities. This explain why a large proportion of the Nigeria population lives near water bodies such as Rivers, reservoirs, lakes, swamps and coastal, lagoons. Many depend heavily on the resources of such water bodies as their main source of animal protein and family income (Haruna et al., 2006). Water from Rivers have been employed for different purposes in different sectors of human development such as public water supply, aquaculture, transportation, industries, agriculture, cleaning and many other domestic purposes. Therefore owing to its multi uses, it has been felt as necessary to monitor water quality of River ecosystems all around the world in order to assess their capacity of production, potential of utility and for planning restorative and future measures (Das and Sinha, 1993). But unfortunately these resource has been polluted throughout the world and still under further contamination. At source, water is relatively pure, but it is contaminated on account of different reasons including its use, land use, urbanization, industrialization, agricultural runoffs, elevation in the use of chemicals, abstractive utilization of water, household use of chemicals like detergents and soaps etc. (Ullah et al., 2014c). Dams, Wells, Rivers etc. play vital and extraordinary role in agriculture, fishery, and electricity, industries along with its huge use for domestic and drinking purpose. Contamination of water primarily influences its chemical nature and also damages the community alarming the delicate food web. Miscellaneous uses of water reservoirs are 
seriously diminished because of contamination and pollution. Pollution of water is a universal problem, so its active ensuring is required (Altaf et al, 2013 and Dhirendra et al., 2009). Countless factors are responsible for water pollution, which makes it moderately unbefitting for life. Such factors includes: Emancipation of sewage, which affects the dissolved oxygen and nutrient contents of water leading to destabilization and unbalanced aquatic life. Pollution effortlessly rises and increases with increase in population (Oluyemi et al., 2010). It is a communal practice of those people who live near the River catchments to discharge their excreta and domestic wastes into the Rivers. Both wild and domestic animals' use same drinking water and contaminates and pollutes water through direct defecation and urination (Ugwu et al., 2012). Both physical and chemical properties of water are frequently changed when it is contaminated with heavy metals and other pollutants, which makes water inappropriate and inconvenient for plant growth and other activities. $\mathrm{pH}$, Organic matter, clay minerals, redox potential, temperature and interrelationships between heavy metals are all themselves physicochemical factors which affect the relationship between microorganisms and toxic metals (Mlitan et al., 2015). River Niger is the main source portable water for to a great number of people in the continent of Africa, Nigeria and Kogi state. This study will provide basic information on the physicochemical parameters that promote the growth of phytoplankton and zooplanktons.

\section{MATERIALS AND METHODS}

Study area: The study was carried out in the portion of the lower River Niger that falls in Ajaokota $\left(6^{0} 45^{\prime} \mathrm{E}\right.$, $6^{0} 41^{\prime} \mathrm{E}$ ) and Lokoja $\left(7^{0} 48^{\prime} \mathrm{N}, 7^{0} 28^{\prime} \mathrm{N}\right.$ ) (a confluence town of River Niger and Benue) local government areas of Kogi state. The wet season begins mostly in the late April and end in late October. Sampling was carried out in three months (January to April) water sample were obtained from three sampling stations on the lower Niger River which are Kpata, Adankolo and Gadumo station. The sampling station are located few meters away from the bank. The River covers part of Bassa, Igalamela-odolu, Kabba Bunu, Idah, Ajaokuta, Ibaji and Kogi local government area of Kogi State, Nigeria and falls within the humid tropical rain forest of Nigeria (Fig 1).

Water Sample Collection: Water samples were collected twice a month (first and fourth week) from $5^{\text {th }}$ January to $23^{\text {th }}$ April, 2018. A total of 24 samples for the study period. The samples were collected in clean plastic bottles of 2 litre capacity, the bottles were soaked in iodide solution for four days in the laboratory, and the solution was then poured out and rinsed thoroughly with distilled water to sterilize (Haruna, 1992). At the River bank the bottle were rinsed thoroughly with the River water before collecting the samples. One samples was collected at the centre of the River, $10 \mathrm{~cm}$ below the surface at each station (i.e. kpata, Adankolo and Gadumo station) on the first and fourth week of the month. All the samples were collected between 6am to $8 \mathrm{am}$.

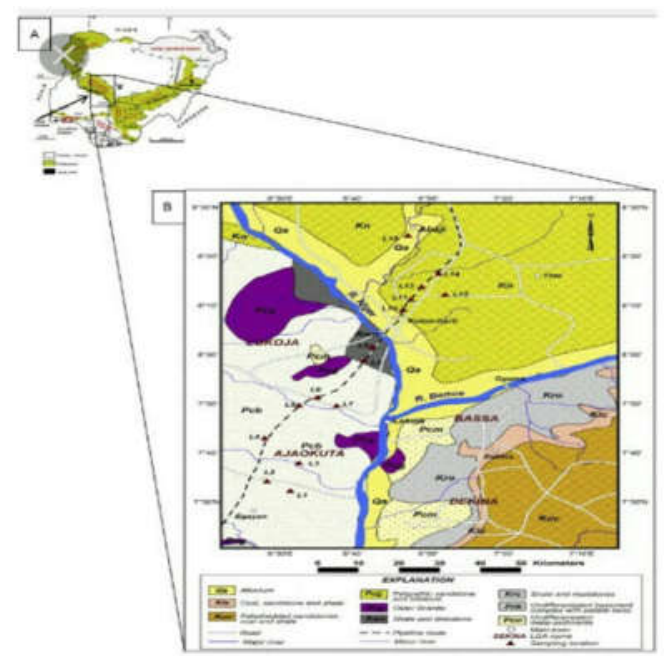

Fig 1: Map of Kogi state showing Lokoja and the lower River Niger in the state and the three sampling station (kpata, Adankolo and Gadumo station). Source: Sciencedirect.com

Determination of the Physicochemical Parameter of the River: Some parameters (Temperature, dissolved oxygen, $\mathrm{pH}$, electrical conductivity and transparency) were measured on site using automatic readers while others which include phosphate, nitrate, biochemical oxygen demand) were analysed in the lab immediately after collection.

Water Temperature: The temperature of the sampling stations was measured using the mercury in glass thermometer calibrated from $0^{0} \mathrm{c}$ to $110^{\circ} \mathrm{c}$, the measurement was done by dipping the thermometer into the river at about $5 \mathrm{~cm}$ below the surface level, and the values were recorded.

$p H$ : The $\mathrm{pH}$ was measured using the $\mathrm{pH} 2606$ meter. The probe of the $\mathrm{pH}$ meter was dipped into the River. The meter reading came to equilibrium and the reading was recorded.

Electrical Conductivity: The probe of the instrument (conductivity meter DDS-307) was rinsed with distilled water and then dipped into the sample. It was allowed for sometimes for the reading to stabilize and the reading was recorded. 
Dissolved Oxygen: The instrument (portable dissolved oxygen analyser model JPB-607) was switched on and the probe was dipped into the water for about 5 minute for the reading to stabilize. The reading was then recorded.

Transparency: A Secchi disc which is about $20 \mathrm{~cm}$ in diameter painted black and white quadrants and attached to a calibrated line was used. The measurement was achieved by lowering the secchi disc into the water until it disappears; the station was marked with a masking tape on the rope attached to the disc. The secchi disc was then raised until it appeared, the station was also measured and the reading taken by measuring with a tape rule. The average depth of disappearance and reappearance was recorded as the depth of the secchi disc transparency.

Biochemical Oxygen Demand (BOD): BOD measurement requires taking two measurements. One was measured immediately for dissolved oxygen (initial) using dissolved oxygen meter on site, the second is incubated in the lab for 5 days by rapping the sample in a black polythene bag, the dissolved oxygen was then measured (final). These represent the amount of oxygen consumed by micro-organisms to break down the organic matter present in the sample during the incubation period.

Phosphate: 50ppm of phosphorus was prepared from $1000 \mathrm{ppm}$, and from it $0.2,0.4,0.8$ and $1.0 \mathrm{ml}$ were pipetted to different standard flasks. $8 \mathrm{ml}$ of ascorbic acid solution was added and make up to $50 \mathrm{ml}$ with distilled water. $25 \mathrm{ml}$ of water samples were pipetted into $50 \mathrm{ml}$ with distilled water. $8 \mathrm{ml}$ of ascorbic solution was added and made up to $50 \mathrm{ml}$. the solution was allowed to stand for 30 minutes and absorbance was read from spectrophotometer at $660 \mathrm{~nm}$. The graph of absorbance was plotted against concentration and samples concentration was evaluated from the graph. The phosphate was obtained by multiplying the reading from the graph by $80 \mathrm{mg} / 1$ (APHA, 1985).

Nitrate: In determining nitrate concentration, $0.5 \mathrm{ml}$ of each sample was pipetted into test tubes; $1 \mathrm{ml}$ of $5 \%$ salicylic acid solution was added to each test tube and mixed thoroughly. This was allowed to stand for 30 minutes, after which $10 \mathrm{ml}$ of $4 \mathrm{M}$ of $\mathrm{NaOH}$ solution was added. It was allowed to stand for one hour for colour development and 12 hours for colour stabilization. The absorptions were read from spectrophotometer at $410 \mathrm{NM}$. Reading from the graph was multiplied by a factor of $4.6 * 10^{4}$ (APHA, 1985).

Statistical Analysis: Data collected were subjected to analysis of variance (ANOVA) and difference between treatments means were separated using Duncan's multiple range test (Steel and Torrie, 1980). Statistical software package- SPSS was used to analyse the data.

\section{RESULTS AND DISCUSSION}

Temperature: The mean temperature values ranged from $23.55-28.35^{\circ} \mathrm{C}$ at Kpata station, $24.65-29.75^{\circ} \mathrm{C}$ at Adankolo station and $23.90-28.90^{\circ} \mathrm{C}$ at Gadumo station. The highest temperature mean value of $26.80{ }^{\circ} \mathrm{C}, 27.63{ }^{\circ} \mathrm{C}$, and $27.20{ }^{\circ} \mathrm{C}$ were recorded in the month of April at Kpata and Adankolo and in the month of March in Gadumo station, while the lowest temperature value of $23.90^{\circ} \mathrm{C}, 24.85^{\circ} \mathrm{C}$ and $24.85^{\circ} \mathrm{C}$ were recorded in the month of February at Kpata station and in January at Adankolo and Gadumo station. The total mean value of the three stations was $25.76^{\circ} \mathrm{C}, 26.41^{\circ} \mathrm{C}$ and $26.51^{\circ} \mathrm{C}$.

$p H$ : The mean $\mathrm{pH}$ values ranged from 6.69-8.15 at Kpata station, 6.60-8.30 at Adankolo station and 6.108.20 at Gadumo station. The highest $\mathrm{pH}$ mean value of $7.73,8.23$, and 8.10 were recorded in the month of February at Kpata station and in April at Adankolo and Gadumo stations, while the lowest $\mathrm{pH}$ value of 6.73 , 7.18 and 6.20 were recorded in the month of March at Kpata and Adankolo stations and in January at Gadumo station. The total mean value of the three stations were 7.21, 7.67 and 6.91.

Electrical Conductivity: The mean electrical conductivity values ranged from $68.50-135.50 \mu \mathrm{S} / \mathrm{cm}$ at Kpata station, $68.00-122.50 \mu \mathrm{S} / \mathrm{cm}$ at Adankolo station and $68.00-122.50 \mu \mathrm{S} / \mathrm{cm}$ at Gadumo station. The highest electrical conductivity mean value of 106.75 $\mu \mathrm{S} / \mathrm{cm}, 95.25 \mu \mathrm{S} / \mathrm{cm}$, and $104.25 \mu \mathrm{S} / \mathrm{cm}$ were recorded in the month of January at Kpata, Adankolo and Gadumo stations, while the lowest electrical conductivity value of $77.75 \mu \mathrm{S} / \mathrm{cm}, 84.00 \mu \mathrm{S} / \mathrm{cm}$ and $81.50 \mu \mathrm{S} / \mathrm{cm}$ were recorded in the month of March at Kpata and Gadumo stations and in April at Adankolo station. The total mean value of the three stations were $88.31 \mu \mathrm{S} / \mathrm{cm}, 90.06 \mu \mathrm{S} / \mathrm{cm}$ and $93.75 \mu \mathrm{S} / \mathrm{cm}$.

Dissolved Oxygen (DO): The mean dissolved oxygen (DO) values ranged from $6.10-9.30 \mathrm{mg} / \mathrm{l}$ at Kpata station, $5.65-7.78 \mathrm{mg} / \mathrm{l}$ at Adankolo station and 6.10$9.30 \mathrm{mg} / \mathrm{l}$ at Gadumo station. The highest dissolved oxygen (DO) mean value of $7.23 \mathrm{mg} / 1,7.67 \mathrm{mg} / \mathrm{l}$, and $8.35 \mathrm{mg} / \mathrm{l}$ was recorded in the month of April at Kpata, Adankolo and Gadumo stations, while the lowest dissolved oxygen (DO) value of $77.75 \mathrm{mg} / 1,84.00$ $\mathrm{mg} / 1$ and $81.50 \mathrm{mg} / 1$ were recorded in the month of March at Kpata, Adankolo and Gadumo stations. The total mean value of the three stations were $6.34 \mathrm{mg} / \mathrm{l}$, $6.72 \mathrm{mg} / \mathrm{l}$ and $7.36 \mathrm{mg} / \mathrm{l}$. 
Transparency: The mean transparency values ranged from $0.31-0.60 \mathrm{~m}$ at Kpata station, $0.31-0.60 \mathrm{~m}$ at Adankolo station and $0.30-0.44 \mathrm{~m}$ at Gadumo station. The highest transparency mean value of $0.55 \mathrm{~m}, 0.60 \mathrm{~m}$, and $0.42 \mathrm{~m}$ were recorded in the month of April at Kpata station, Adankolo station and in April and February at Gadumo station, while the lowest transparency value of $0.31 \mathrm{~m}, 0.32 \mathrm{~m}$ and $0.33 \mathrm{~m}$ were recorded in the month of April at Kpata, Adankolo and Gadumo station. The total mean value of the three stations was $0.40 \mathrm{~m}, 0.44 \mathrm{~m}$ and $0.40 \mathrm{~m}$.

Biochemical Oxygen Demand: The mean biochemical oxygen demand (BOD) values ranged from 2.10-2.95 $\mathrm{mg} / \mathrm{l}$ at Kpata station, $2.05-3.25 \mathrm{mg} / \mathrm{l}$ at Adankolo station and $2.10-4.00 \mathrm{mg} / \mathrm{l}$ at Gadumo station. The highest biochemical oxygen demand (BOD) mean value of $2.83 \mathrm{mg} / \mathrm{l}, 2.85 \mathrm{mg} / \mathrm{l}$, and $3.05 \mathrm{mg} / \mathrm{l}$ was recorded in the month of April at Kpata, Adankolo and in February at Gadumo station, while the lowest biochemical oxygen demand (BOD) value of 2.15 $\mathrm{mg} / \mathrm{l}, 2.13 \mathrm{mg} / \mathrm{l}$ and $2.13 \mathrm{mg} / \mathrm{l}$ was recorded in the month of March at Kpata and in march at Adankolo and Gadumo station. The total mean value of the three stations was $2.44 \mathrm{mg} / 1,2.44 \mathrm{mg} / \mathrm{l}$ and $2.68 \mathrm{mg} / \mathrm{l}$.

Phosphate: The mean phosphate values ranged from $0.48-0.61 \mathrm{mg} / \mathrm{l}$ at Kpata station, $0.51-0.65 \mathrm{mg} / \mathrm{l}$ at Adankolo station and $0.49-0.64 \mathrm{mg} / \mathrm{l}$ at Gadumo station. The highest phosphate mean value of 0.60 $\mathrm{mg} / 1,0.65 \mathrm{mg} / \mathrm{l}$, and $0.60 \mathrm{mg} / \mathrm{l}$ was recorded in the month of January and February at Kpata station, and in march Adankolo and Gadumo station, while the lowest phosphate value of $0.48 \mathrm{mg} / 1,0.52 \mathrm{mg} / 1$ and $0.51 \mathrm{mg} / 1$ were recorded in the month of April at Kpata and Gadumo stations and January and April at Gadumo station. The total mean value of the three stations was $2.44 \mathrm{mg} / \mathrm{l}, 2.44 \mathrm{mg} / \mathrm{l}$ and $2.68 \mathrm{mg} / \mathrm{l}$.

Nitrate: The mean nitrate values ranged from $0.02-$ $0.05 \mathrm{mg} / \mathrm{l}$ at Kpata station, $0.02-0.03 \mathrm{mg} / \mathrm{l}$ at Adankolo station and $0.02-0.04 \mathrm{mg} / \mathrm{l}$ at Gadumo station. The highest nitrate mean value of $0.04 \mathrm{mg} / 1,0.18 \mathrm{mg} / \mathrm{l}$, and $0.03 \mathrm{mg} / 1$ were recorded in the month of January at Kpata station, and in march at Adankolo station and in February, march and April at Gadumo station, while the lowest phosphate value of $0.02 \mathrm{mg} / 1,0.02 \mathrm{mg} / \mathrm{l}$ and $0.02 \mathrm{mg} / \mathrm{l}$ were recorded in the month of march and April at Kpata station and in April at Adankolo station and January at Gadumo station. The total mean value of the three stations were $0.03 \mathrm{mg} / 1,0.02 \mathrm{mg} / \mathrm{l}$ and 0.03 $\mathrm{mg} / \mathrm{lThe}$ results of the mean value of the physicochemical parameters of lower river Niger at Kpata, Adankolo and Gadumo stations are shown in Figure 4.1 to 4.8 below:

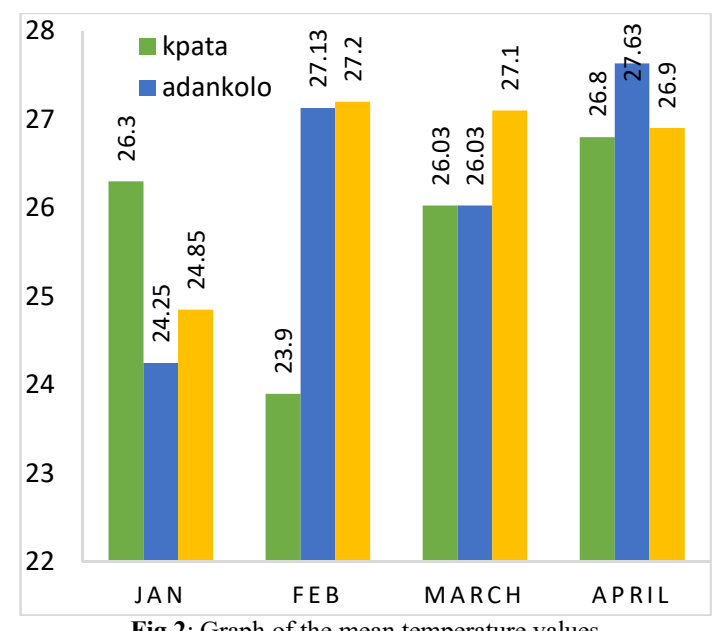

Fig 2: Graph of the mean temperature values

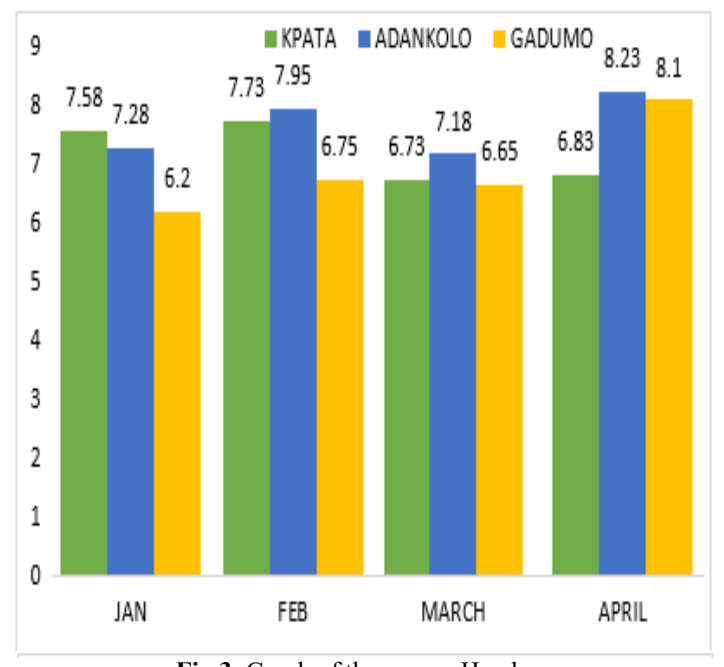

Fig 3: Graph of the mean $\mathrm{pH}$ values

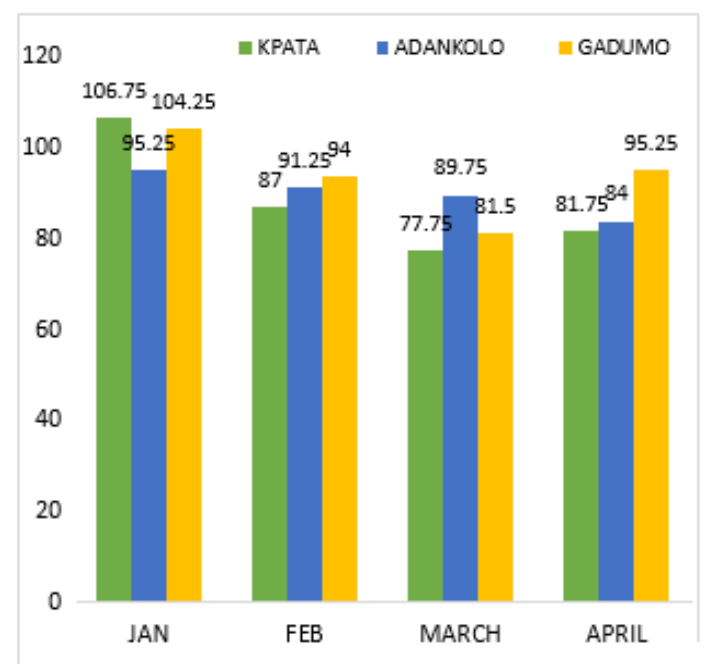

Fig 4: Graph of the mean electrical conductivity values 


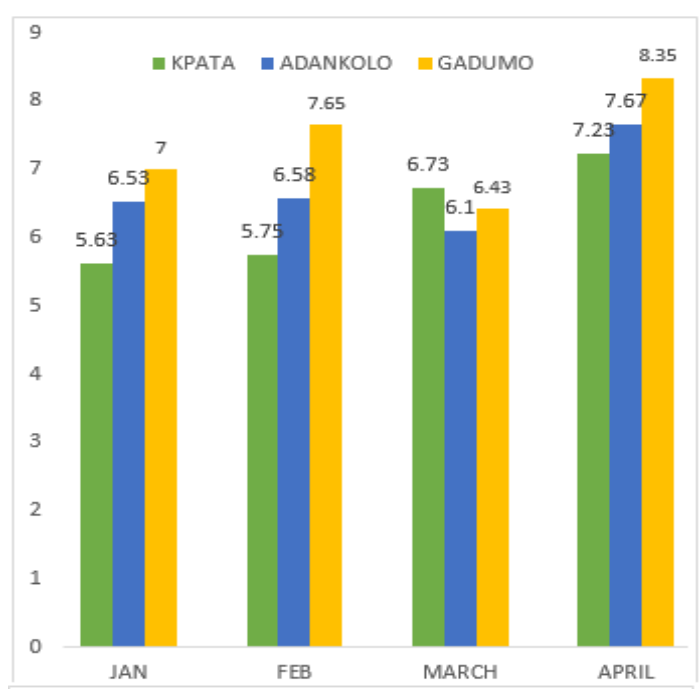

Fig 5: Graph of the mean dissolved oxygen values

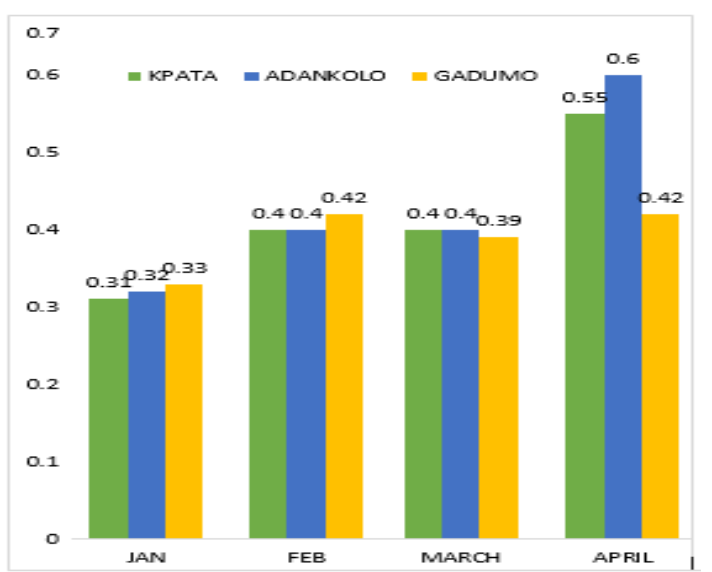

Fig 6: Graph of the mean transparency values

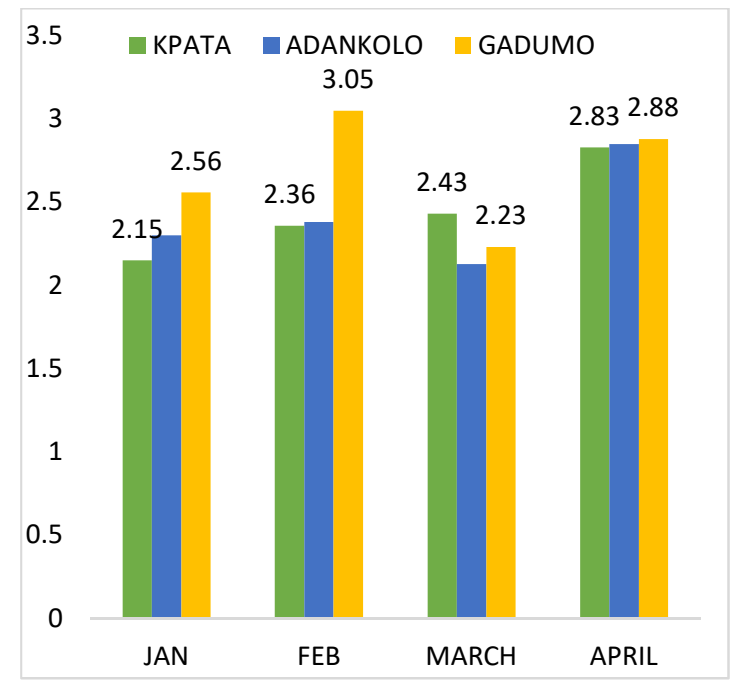

Fig 7: Graph of the mean Biochemical oxygen demand values

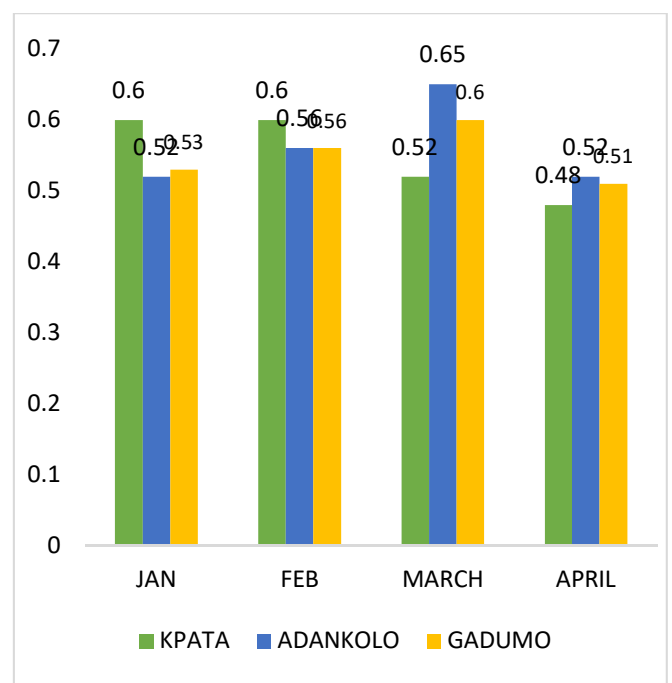

Fig 8: Graph of the mean phosphate values

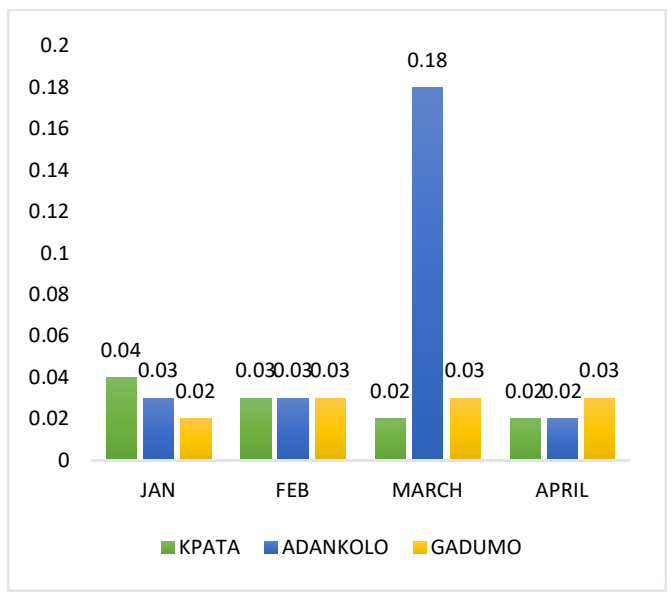

Fig 9: Graph of the mean nitrate values

The mean Water temperature are $25.76^{\circ} \mathrm{C}, 26.41^{\circ} \mathrm{C}$ and $26.51^{\circ} \mathrm{C}$ at Kpata, Adankolo and Gadumo station respectively. A slightly similar mean water temperature of $27.60^{\circ} \mathrm{C}$ was also reported by (Gideon et al., 2013 and Ige et al., 2008) while a slightly lower mean water temperature of $18.44^{\circ} \mathrm{C}$ was reported by (Rauf et al., 2015) in River Kabul, Pakistan the mean temperature of the three stations slightly conform to that reported by (Olatunji, 2011).

The $\mathrm{pH}$ concentration of the study area ranges from 6.69-8.15 at kpata station, 6.60-8.30 at Adankolo and 6.10-8.20 at Gadumo station and a mean $\mathrm{pH}$ of 7.21, 7.67 and 6.91 respectively are circumneutral and thereby suitable for fish growth. This results agree with Ali et al., 2013 who reported a mean $\mathrm{pH}$ of 7.25, 8.17 reported by Rauf et al.,2015 in River Kabul, Pakistan and a range of 6.78-7.50 in Lower River within Lokoja and Ajaokuta local government area. 
Ogolo et al., 2017 reported a mean $\mathrm{pH}$ of 6.51, this value is lower compared to that obtained from Kpata, Adankolo and Gadumo station indicating that the River is more acidic compared to the lower River Niger in this study area. These values conforms to most fresh water $\mathrm{pH}$ (Chapman, 1992). The acceptable range for fish culture is normally between $\mathrm{pH}$ 6.5-8.5 (Swann, 2007). The mean $\mathrm{pH}$ and range of the study area conform to the acceptable range reported by (Swann, 2007). Electrical conductivity of the analysed water samples range from $68.50-135.50 \mu \mathrm{S} / \mathrm{cm}, 68.00$ $122.50 \mu \mathrm{S} / \mathrm{cm}$ and $79.50-112.00 \mu \mathrm{S} / \mathrm{cm}$ this values are slightly lower $99.0 \mu \mathrm{S} / \mathrm{cm}$ and $180.5 \mu \mathrm{S} / \mathrm{cm}$ reported by Dimowo (2013) in River Ogun in the month of February 2012 and December, 2011 respectively, $74.6-510 \mu \mathrm{S} / \mathrm{cm}$ reported by Raji et al., (2015) in River Sokoto, $113-287 \mu \mathrm{S} / \mathrm{cm}$ reported by victor et al., (2013) in the flooded areas of lower River Niger in Lokoja. Lower value was observed of $6.0-17.0 \mu \mathrm{S} / \mathrm{cm}$ reported by (Sikoki and Anyanwu 2013).

The mean Dissolved oxygen concentration for Kpata, Adankolo and Gadumo station are $6.34 \mathrm{mg} / 1,6.72 \mathrm{mg} / 1$ and $7.36 \mathrm{mg} / 1$, while the range are $5.10-7.65 \mathrm{mg} / 1,5.65-$ $7.78 \mathrm{mg} / 1$ and $6.10-9.30 \mathrm{mg} / 1$ respectively. The range compares favourably with $7.20 \mathrm{mg} / 1$ to $9.25 \mathrm{mg} / 1$ reported by Ali et al., 2013 in lower River Niger, lokoja, $3.22 \mathrm{mg} / 1$ to $6.42 \mathrm{mg} / 1$ reported by Adeola et al., (2015) in Nwala creek. A transparency of $0.20 \mathrm{~m}$ to $0.70 \mathrm{~m}$ was reported by Dimowo, (2013) in River Ogun, this result was slightly below the range observed in the study area which are $0.31 \mathrm{~m}-0.60 \mathrm{~m}$, $0.31 \mathrm{~m}-0.60 \mathrm{~m}$ and $0.30 \mathrm{~m}-0.44 \mathrm{~m}$ for Kpata, Adankolo and Gadumo station. The highest transparency value of $0.6 \mathrm{om}$ was observed at Adankolo station, the high water transparency at this station could be as a result of the low human activities around the River compared to the Kpata stations. While the lowest transparency of $0.31 \mathrm{~m}$ was recorded at Kpata station due to increase human activities. Boyd (1998) reported 0.30-0.60m as the acceptable range of dissolved oxygen required for the optimum growth and reproduction of freshwater fishes. The range of transparency recorded at the three stations fell within the acceptable range reported Boyd (1998). Thus the River is suitable for fish growth and reproduction. The Biochemical oxygen demand values ranged from $2.10 \mathrm{mg} / 1-2.95 \mathrm{mg} / 1,2.05 \mathrm{mg} / 1-3.25 \mathrm{mg} / 1$ and $2.10 \mathrm{mg} / 1-4.00 \mathrm{mg} / \mathrm{l}$ for Kpata, Adankolo and Gadumo station, the observed range are slightly similar to $1.27 \mathrm{mg} / 1-2.57 \mathrm{mg} / \mathrm{l}$ reported by Ali et al., (2013) in lower River Niger, Lokoja, 3.5mg/l to $3.9 \mathrm{mg} / 1$ reported by Stanley et al., (2017) in new Calabar River. The mean BOD values of Kpata, Adankolo and Gadumo station of the lower Niger River were above $2 \mathrm{mg} / \mathrm{L}$ and their statistically difference with the three stations may be attributed to the observed human activities such as washing, dumping of refuse and sewage into the River channel. Based on classification of aquatic bodies, unpolluted (BOD $<1.0 \mathrm{mg} / \mathrm{L}$ ), moderately polluted (BOD $<10.0 \mathrm{mg} / \mathrm{L}$ ) and heavily polluted (BOD $>10.0 \mathrm{mg} / \mathrm{L}$ ) (Maria 1983 and Adakole et al., 2002). BOD above $1 \mathrm{mg} / \mathrm{L}$ is associated with waste water contamination (UNESCO, WHO and UNEP, 1998). Based on the classification of aquatic bodies, the mean BOD of lower River Niger at Kpata, Adankolo and Gadumo station was less than $10 \mathrm{mg} / 1$, thus it is moderately polluted and suitable for the growth and survival of aquatic live such as fish. Phosphate concentration in this investigation varied from $0.48 \mathrm{mg} / 1-0.61 \mathrm{mg} / \mathrm{l}$, $0.51 \mathrm{mg} / 1-0.65 \mathrm{mg} / 1$ and $0.49-0.64 \mathrm{mg} / 1$ for Kpata, Adankolo and Gadumo station. The observed range is similar to $0.4 \mathrm{mg} / 1$ to $0.6 \mathrm{mg} / 1$ reported by Rauf et al., (2015) and are lower than $0.33 \mathrm{mg} / 1-3.30 \mathrm{mg} / 1$ reported by Ali et al., (2013) in lower River Niger at Lokoja and also comparable to the $0.04 \mathrm{mg} / \mathrm{l}-$ $0.78 \mathrm{mg} / 1$ gotten by Wokoma (2010) in the Elechi Creek. $0.11 \mathrm{mg} / \mathrm{l}-0.80 \mathrm{mg} / \mathrm{l}$, ( Wokoma and Njoku, $2017)$ in the lower Sombreiro River, Niger delta and $0.11-0.59 \mathrm{mg} / 1$ reported by Raji et al., (2015) in River Sokoto, $0.01 \mathrm{mg} / 1$ to $0.7 \mathrm{mg} / 1$ observed in River Ogun between February and March (Dimowo, 2013). The range of phosphate recorded at the three stations fell within the acceptable range reported by Swann (2007). Thus the River is suitable for fish growth and reproduction. But the phosphate level in the study area was low compared to the value reported by Ali et al., (2013), this overall low level of phosphate is probably due to the absence or little amount of rainfall to wash fertilizer from farmland into the River as the value obtained by Ali et al., (2013) include both the rainy and dry season, in the rainy season large amount of phosphate from fertilizer are wash into the River through runoffs. The nitrate concentration in the study area are lower compared to $6.6 \mathrm{mg} / 1-19.7 \mathrm{mg} / 1$ reported by Raji et al., 2015, in River Sokoto, $1.50 \mathrm{mg} / 1$ $-17.5 \mathrm{mg} / 1$ reported by Ali et al., 2013 in lower River Niger, $0.05 \mathrm{mg} / \mathrm{l}-7.75 \mathrm{mg} / \mathrm{l}$ reported by Wokoma and Njoku et al., 2017 and $0.013 \mathrm{mg} / \mathrm{l}-0.158 \mathrm{mg} / 1$ gotten by Edoghotu and Aleleye - Wokoma (2007), 0.0 $1.72 \mathrm{mg} / \mathrm{l}$ observed by Ogamba et al., (2004) and slightly similar to $0.02 \mathrm{mg} / \mathrm{l}$ in Oji-Aji location reported by Gideon et al., (2013) in River Okura, 0.0 - $0.6 \mathrm{mg} / \mathrm{l}$ by Sikoki and Anyanwu (2013), $0.24 \mathrm{mg} / \mathrm{l}$ $0.33 \mathrm{mg} / 1$ reported by (Stanley et al., 2017). The highest nitrate level of $0.05 \mathrm{mg} / \mathrm{l}$ was gotten at Kpata station this might be due to human activities such as irrigation near the River, discharge of domestic sewage and other organic waste material into the River at that station. The nitrate in the study area was low, this overall low level of nitrate is probably due to the absence or little amount of rainfall to wash fertilizer from farmland into the River. High nitrate levels 
greater than $1 \mathrm{mg} / \mathrm{L}$ are not good for aquatic life (Johnson et al., 2000). The nitrate observed at the three station are less than $1 \mathrm{mg} / 1$ and good for aquatic life including fish. Boyd (1998) and Swann (2007) reported $0.2-10 \mathrm{mg} / 1$ and $0.0-30 \mathrm{mg} / 1$ respectively as the acceptable range of nitrate required for the optimum growth and reproduction of freshwater fishes. The range of nitrate recorded at the three stations fell within the acceptable range reported by Boyd (1998) and Swann (2007). Thus the River is suitable for fish growth and reproduction.

Conclusion: The results showed that water from lower River Niger at Lokoja and Ajaokuta local government area, having passed majority of the water quality criteria for productivity, is a productive water system.

Acknowledgment: Our gratitude goes to the technical staff of the department of Fisheries and aquaculture, Kogi State University, Anyigba for their support.

\section{REFERENCES}

Ali, MZ; Michael Yahuza, T (2013). PhysicoChemical Characteristics and Phytoplankton Abundance of the Lower Niger River, Kogi State, Nigeria. J. Environ. Sci. Toxic. Food. Tech. 2. 3137

. Altaf, H; Sulehira, AQ; Ijaz, M; Maqbool (2013). A "Monthly variations in physicochemical parameters of a flood plain reservoir on River Ravi near Balloki Headworks Pakistan. Biologica. 59. 371-377.

Boyd, CE (1998). Water quality for pond aquaculture. Research and development series No.43 international centre for aquaculture and aquatic environments, Alabama Agricultural Experiment Station, Auburn University, Alabama.

Chapman, D (1992). Water Quality Assessments - A Guide to the Use of Biota, Sediments and Water in Environmental Monitoring, Chapman and Hall: London; pp. 76-78.

Chapman, D. (1996). Water Quality Assessments: A Guide to the Use of Biota, Sediments and Water in Environmental Monitoring, 2nd ed.; Ed.; Chapman and Hall: London, UK.

Das, NK; Sinha, RK (1993). Assessment of water quality of Ganga River, Patna, India. Environmental Ecology 11, 829-832.

Dhirendra, MJ; Kumar, A (2009). "Studies on Physicochemical parameters to asseswater quality of River Ganga for drinking purpose in Haridwar District", Rasayan J. Chem. 2. 195-203.

Dimowo, BO. (2013) Assessment of Some Physicochemical Parameters of River Ogun (Abeokuta, Ogun State, Southwestern Nigeria) in Comparison With National and International Standards, Inter. J. Aquaculture. 3 (15) 79-84

Gideon, YB; Fatoye, FB; Omada,, J I (2013). Quality Assessment of Physico-Chemical Characteristics of Okura River, Kogi State, Nigeria. Inter. J. Sci. Tech. (2)12, 891-900.

Haruna, AB (1992). Aspects of water quality and biology of fishes of Jakara lake, Kano State, Nigeria. Mac thesis.pp 151.

Haruna, AB; Abubakar, KA; Ladu, BMB (2006). An assessment of physico- chemical parameters and productivity status of Lake Geriyo, yola, adamawa state, Nigeria. Biol.Environ. Sci. J. Tropics, 3(1); 18-23.

Ige, OO; Bale, RB; Olashehinde, PI. (2008). PhysicoChemical Characteristics of Water Pollution Sources in Imeko, South western Nigeria. Wat. Res. 18. 32-36.

Malik, GM; Joshi, MP; Zadafiya, SK; Raval, VH (2012). Study on Physico Chemical Characterization of Some Lotic Suhjystem of South Gujarat, India. Res. J. Chem. Sci. 2(1), 8385 .

Rauf , M; Naeem, U; Ullah, S; Abdul, H; Hussain, S; Faiz, R; Mushtaq, K (2015). Physiochemical Investigation of River Kabul at Michini, Khyber Pakhtunkhwa, Pakistan. J. Biodiv. Environ. Sci. 7(3); 280-291.

Sikoki, FD, Anyanwu, N (2013). Spatial and Temporal Variations of Physicochemical Variables in a Small Pristine Stream in Niger Delta, Nigeria. $J$. Fisheries. Aqua. Sci. 8: 129-135.

Stanley, HO; Immanuel, OM; Nwagboso A (2017). Water Quality Assessment of the New Calabar River. J. Appl. Life. Sci. Inter. 15(2): 1-5.

Steel, RG; Torrie, JH (1980). Principles and procedures of statistics. A Biometrical Approach.

Swann, L (2007). A fish farmer's guide to understanding water quality. www.aquaric.org/publicat/state/il-in/as503.htm.Retrieved June 5, 2007. Topic center on 
water. 6(1): 1-65 Tsai, S.-J., Chen, J.-C., 2002. Acute toxicity of nitrate on Penaeus monodon juveniles at different salinity levels. Aquaculture 213, 163-170.

Ullah, S; Javed, MW, Rasheed, SB; Jamal, Q; Aziz, F; Ullah, S (2014c). Assessment of groundwater quality of district Dir Lower Pakistan. Inter. J. Biosci. 4(8), 248-255.

Ullah, S; Ullah, N; Rahman K, Khan TM, Jadoon, MA; Ahmad, T. (2014b). Study on Physicochemical Characterization of Konhaye Stream District Dir Lower, Khyber Pakhtunkhwa Pakistan. World J. Fish. Mar. Sci. 6(5), 461470.
Ullah, S; Zorriehzahra, MJ (2014). Ecotoxicology: A review of Pesticides induced toxicity in fish. $A d v$. Animal. Vet. Sci. 3(1), 40-57.

UNESCO, WHO, UNEP. (1996). Water quality assessment- A guide to the use of biota, sediments and water in environmental monitoring, $\mathrm{E}$ and $\mathrm{FN}$ Spoon. Cambridge, Great Britain. University of Rhode Island; http://www.uri.edu/ce/wq/ww/Publications

Wokoma, OAF; Njoku K. U. (2017). Physical and Chemical Characteristics of the Lower Sombreiro River, Niger Delta, Nigeria. Appl. Sci. Reports 20 (1), 11-16.

World Health Organisation, Guidelines for drinking water Quality (2006). WHO Press, Geneva, Switzerland (2) 1, 595 